\title{
A Conceptual Framework for Transport Infrastructure PPP Project Credit Assessments
}

\author{
Aristeidis Pantelias', Athena Roumboutsos ${ }^{2, *}$ \\ ${ }^{1}$ University College London, Bartlett School of Construction and Project Management, 1-19 Torrington Place, London, UK \\ ${ }^{2}$ University of the Aegean, Dpt. Shipping, Trade and Transport, 2A Korai str., Chios, Greece \\ *Corresponding author: athena@aegean.gr
}

\begin{abstract}
Project credit assessments have been increasingly used in order to evaluate the creditworthiness of infrastructure projects. In light of the benefits that can be achieved from changing the financial basis of such projects during their life-cycle, the accuracy and comparability of project credit assessments become of cardinal importance to the successful financing or re-financing of a project. This paper proposes a conceptual framework for assessing project creditworthiness based on the study of risks that are encountered during the life-cycle of transport infrastructure projects. The proposed framework is based on a generic classification of risks and has risk allocation among the project's counterparties at its core. The proposed framework intends to reflect the true risk status of such projects and consider asset-specific characteristics that are important to the role and operation of transport infrastructure. The findings of this paper aim to serve as a starting point for future research on the development of transport infrastructure project credit assessments that can overcome potential limitations and accurately reflect risk bearing and coping.
\end{abstract}

Keywords: project finance, credit assessment

Cite This Article: Aristeidis Pantelias, and Athena Roumboutsos, "A Conceptual Framework for Transport Infrastructure PPP Project Credit Assessments.” Journal of Finance and Economics, vol. 3, no. 6 (2015): 105-111. doi: 10.12691/jfe-3-6-1.

\section{Introduction}

The use of Public-Private Partnerships (PPPs) in support of public infrastructure programmes has been increasing over the past decades. These investments in principal concern large sunk costs, while the procurement model bundles investment and service provision of infrastructure into a single long-term contract in the range of 20 to 35 (and even more in some cases) years. A key parameter of the PPP model of infrastructure delivery is the private sector participation as financier, designer, builder and operator. During the operation of the project, the private partner receives a stream of payments as compensation. These payments cover both the initial investment - the so-called capital expenses (capex) - and operation and maintenance expenses (opex). Depending on the contractual agreement, revenues may be secured directly from charging the users (e.g. tolls for road use or tariffs for port users) or indirectly from the taxpayers (e.g. availability fees from government agencies).Other less common models involve a mix of varying levels of direct and indirect payments.

PPP advocates emphasise Value for Money (VfM) creation and capture, based on a number of attributes of this delivery model: equitable risk allocation, design studies and construction practices leading to optimal operation and asset maintenance (life cycle management considerations), and private sector efficiencies and skills in the provision of a public service (or asset). However, most governments have employed the model in order to gain access to additional finance that would remain "off balance sheet" (cf. [1,2]). Some sectors were more favoured than others. The transport infrastructure sector, in particular, has made extensive use of the PPP model. Economic growth coupled with increased traffic demand and the wider acceptance of the "user pays" principle, were few of the reasons supporting this trend.

Project finance has been the predominant vehicle in addressing the financing needs of PPP projects as this financing technique is based on lending against the future cash flows of a project that is legally and economically self-contained. Project finance in general and as applied to PPP projects in particular, has a number of specificities that set it apart from corporate finance transactions. Firstly, the project-investment is governed by an independent company, the SPV (Special Purpose Vehicle). Project sponsors are represented in this company but in most cases this new entity is legally (and fiscally) independent of the sponsors' corporate status. Secondly, project (and investment) risks are not all borne by the SPV. Some, through the (equitable) allocation of risks, are borne by the public counterparty. Thirdly, PPP risks vary over the life cycle of a project. This characteristic may justify changing the sources of finance over the project's life cycle in order to achieve savings and benefit from the different pricing of risk. During construction, expenses are usually financed with sponsor equity (which may be complemented with bridge loans and subordinated or mezzanine debt) and 
bank loans. In some cases, the project may receive government subsidies. Once the project becomes operational, longterm bonds could substitute bank loans and the sponsor's equity may be bought out by a facilities operator, or even by other financial investors, such as institutional investors [3]. In addition, governments in many cases provide various means of support during the operating phase, such as minimum revenue guarantees. However, one very important final characteristic of PPPs is the fact that the asset is of public use. Hence, the public has always vested interest in the project and the provision of the related service(s) and may, therefore, be prepared to go to great lengths in order to guarantee its life-long viability.

This last characteristic allowed risk adverse lenders to get involved in PPP Project Finance transactions and stay longer involved in the project than would be originally expected. Banks, relational or not, have been key lenders of PPP projects with loan tenors extending far after the construction phase was complete. So much so that following the Basel II and III Committee Regulations and their impact on bank debt consolidation long-term loan tenors almost but vanished from the credit markets for a period of time until they started to resurface again as the effects of the crisis and market uncertainty started to abate. This "hiccup" in the credit markets created an obstacle in PPP development, especially in markets which were dependent on bank loans.

Change in the financial basis of projects, which may be considered a normal evolution following their risk profile, is dependent on their financial (credit) assessment. One way to conduct such an analysis is by implementing already existing approaches which assess corporate or structured finance issuers or issues. However, such methods are not always representative of the individual project risk status. Using the structured finance approach has in part been due to the fact that the Basel Accords classify Project Finance within the family of structured finance transactions, under the term "Specialized Lending" [6]. At the same time there are many cases of infrastructure projects that have been financed "on balance sheet” by their sponsors; in such cases reverting to a corporate finance approach makes absolute sense. However, project credit assessments that are predominantly based on corporate finance methodologies may not be appropriate for PPP projects as this paper will try to demonstrate. This is important as, regardless of their underlying methodology, these credit assessments have an effect on the ability of projects to raise initial debt or issue new debt. They also have an increasing impact during project renegotiation and refinancing. Consequently, as credit assessments are evolving to become metrics of cardinal importance to the determination of the financing profile of a project, they should therefore be given increased attention and be subject to continuous scrutiny.

Indeed, as the revenue streams of on-going and new PPPs, especially in the transport sector, are influenced by the changes in the macro-economic environment, project credit assessments become an important indicator of their likelihood of default (including delayed payment of debt) while the financial markets become more dependent on them.

However, this paper professes that there are two important difficulties in achieving reliable credit assessments: i) the fact that SPVs are independent entities with no financial history; and ii) that infrastructure assets have particularities which are not equivalent to commercial investments. In light of the above it is clear that relative ratings are less important than absolute ratings of credit risk, as project characteristics are in most cases very unique to be directly comparable. While, Credit Rating Agencies (CRAs) have a relative good track record with respect to the first, absolute risk ratings have presented limitations [5]. Furthermore, CRAs follow different methodologies and incorporate qualitative elements in their assessments, leading, on occasion, to differences in their assigned ratings. Finally, while the number of PPP projects has increased significantly over the last decades, respective project ratings are scarce. Notably, credit ratings are usually solicited by sponsors and not undertaken arbitrarily by CRAs. This is in line with the fact that PPPs were primarily guaranteed by governments and, therefore, financiers were anticipating limited exposure to credit risks. However, this has changed during the on-going economic crisis due to incidents where the public counterparty's creditworthiness and its ability to honour such guarantees have been called into question.

In response, the present research considers the lifecycle risk profile of infrastructure transport projects and the fundamental structure of PPPs in order to propose a conceptual framework by which to assess the creditworthiness of transport infrastructure projects.

The remaining parts of this paper are structured as follows: the second section covers the background of the study in terms of the analysis of the risk profile of transport PPP projects. Current approaches to assess project creditworthiness and some methodological considerations are reviewed in the third and fourth section, respectively. The methodological approach for the development of the proposed framework is presented in the fifth section. The paper ends with conclusions and suggestions for future research.

\section{Transport PPPs Risk Profile}

Credit assessments concern the evaluation of the likelihood of default on obligations or delayed payment of debt. In the context of PPPs they are directly connected to project risks and their evolution over the life-cycle of the contractual agreement. This section reviews transport PPP project risks as they are reported in literature.

The primary risks transferred within a PPP arrangement are the risks of project financing and project performance (finance and service-based approach, as described by Aziz [1]). However, PPP contractual agreements, incomplete by nature, pose additional risks stemming from the arrangement per se.

Checherita and Gifford [8] discuss risks that can occur during the lifetime of a road infrastructure project. They classify them in two broad categories: common risks and PPP-specific risks. Common risks can arise in any road infrastructure investment, irrespective of the structure of ownership, financing or operation. Grimsey and Lewis [7] have identified nine risks which apply to all infrastructure projects: technical risk, due to engineering and design failures; construction risk, because of faulty construction techniques and cost escalation and delays in construction; operating risk, due to higher operating costs and 
maintenance costs; revenue risks, e.g., due to traffic shortfall or failure to extract resources, the volatility of prices and demand for products and service sold leading to revenue deficiency; financial risks arising from inadequate hedging of revenue streams and financing costs; force majeure risk, involving war and other calamities and acts of God; regulatory/political risks, due to legal changes and unsupportive government policies; environmental risks, because of adverse environmental impacts and hazards; project default, due to failure of the project from a combination of any of the above. Many others have contributed to the list of risks identified, but as Kwak et al. [9] pointed out, there is no list of risk that is applicable to all PPP projects and there is no risk classification approach which is universally accepted as the best. Risks of a PPP project are affected by several factors, such as the type and scale of a project, the country where the project is located, and the type of PPP implemented.
However, there are three characteristics that set transport PPP projects apart [11]: the high sunk costs involved; their positioning as "temporary monopolies" and, finally, their network nature. All three characteristics influence their revenues and, in turn, their financial viability.

As project risks vary over time, the appropriate representation would be over the entire asset life cycle. Pellegrino et al [10] adopted this approach and Roumboutsos et al [12] refined it for the case of transport infrastructure PPPs with an emphasis on current concerns. Figure 1 illustrates risks of transport project PPPs over the asset life cycle. Evidently, with respect to credit assessments the "Development Phase Risks" could bear little significance. In addition, it is interesting to note that with respect to "life-cycle risks" and with the exception of "governance risks", which correspond to the SPV, and "force majeure events" which are completely external to the transaction, all other risks are country- and sector- related.

\begin{tabular}{|c|c|c|c|}
\hline $\begin{array}{l}\quad \begin{array}{l}\text { Development Phase } \\
\quad \text { Risks }\end{array} \\
\text { Bid Cancellation - pre } \\
\text { investment risk } \\
\text { Land use and acquisition risk } \\
\text { Financial close risk } \\
\text { Specifications risk }\end{array}$ & $\begin{array}{l}\text { Construction Phase } \\
\text { Risks } \\
\text { Time overrun risk } \\
\text { Cost Overrun risk } \\
\text { Quality shortfall risk } \\
\text { Permit risks } \\
\text { Innovation risks }\end{array}$ & $\begin{array}{l}\text { Operation Phase } \\
\quad \text { Risks } \\
\text { Cost Overrun Risk } \\
\text { Quality Performance Risk } \\
\text { Revenue Risk } \\
\text { Competition Risks } \\
\text { Network Risks }\end{array}$ & $\begin{array}{c}\begin{array}{c}\text { Transfer } \\
\text { Risks }\end{array} \\
\text { Asset residual value risk }\end{array}$ \\
\hline \multicolumn{4}{|c|}{ Life Cycle Risks } \\
\hline $\begin{array}{l}\text { Political Risks } \\
\text { Legal \& Regulatory Risks } \\
\text { Social - project acceptance } \\
\text { risk }\end{array}$ & Inflation risk & $\begin{array}{l}\text { Force majeure events (nature) } \\
\text { Force majeure events } \\
\text { (political /economic / } \\
\text { social) }\end{array}$ & Governance Risks \\
\hline
\end{tabular}

Figure 1. Typical Transport PPP Project Life Cycle Risks (Source: Adoptedfrom Pellegrino et al [10] and Roumboutsos et al [12])

It is also important to note, that while these risks are many times presented as independent and confined to particular phases of the project (or contract) life-cycle, there is strong correlation between risks of the same group as well as between groups. In addition, over time risks either resolve or materialize bearing a corresponding impact on other risks as they are related to a particular project life cycle phase. In the particular case of credit assessments, the ultimate goal is to identify the correlation of the revenue risk with other prevailing project risks.

Reverting to the benefits of a PPP agreement, these include the equitable allocation of risks among counterparties. The objective is to develop a setting for each specific project where the cost of risks is minimized, hence achieving overall risk efficiency. Ball et al. [13] note that "risk transfer accounted for 60 per cent of the total cost saving for the PFI projects" in the UK PFI analysis of Anderson and LSE Enterprise [14]. Additionally, another study has shown that achieving value for money in 6 out of 17 cases (i.e. 35\%), was entirely due to risk transfer [15].

While some risks could be reasonably allocated a priori, such as construction risk, others are more difficult to assign. Grimsey and Lewis [7] presented a risk matrix for the allocation of risks in PPP projects. In this proposed matrix, no risk category is assigned in total to a specific party. Similar were findings of a recent expert survey conducted by Roumboutsos et al [12]. Moreover, the diversity of risk settings renders risk allocation scenarios difficult in the transport sector. There is no uniform format for risk allocation and the most appropriate combination must be considered on a case by case basis [18]. More recently, the European PPP Expertise Centre (EPEC) [19] noted that "standard risk allocation" is not sufficient to satisfy the private sector under the current financial crisis and proposed the use of state guarantees to enhance PPP bankability and attractiveness to financial investors for a number of PPP risks, namely: company default risks; demand / usage risks; construction risks; technology risks; sub-sovereign risks; policy risks; macroeconomic risks; and residual value risks. This latter contribution renders the credit assessment even more complex as emphasis is shifted to the assessment of the public sector counterparty (i.e. the country/sovereign).

According to Loosemore et al. [16], the effective distribution of risks, should follow established rules, whereas a risk is undertaken by a party when this party has:

- Full awareness of the risk to be undertaken

- Greater capacity to manage the risk effectively and efficiently

- The capacity and resources to cope with the risk eventuating

- The preference to undertake the specific risk

- The possibility to charge the respective risk premium. 
These guidelines pose a significant contradiction, as the party most capable to manage the risk may not always be the one most able to cope with the risk materialising. This is particularly true for transport PPPs, which concern large sunk investments making the public sector typically more able to absorb the respective cost of risk. State guarantees are a characteristic example of addressing such a need. Other State/government/public authority forms of assistance or credit enhancement may contribute to the same purpose. However, the more such measures are included in support of the agreement, the more the assessment of creditworthiness is shifted from the project to the public sector counterparty.

\section{Existing Approaches to Project Credit Assessment}

Given the importance of credit assessments to the project finance and PPP industry, it is not surprising that all three major CRAs publish their own methodologies applied for rating infrastructure projects. These methodologies have been developed over the last 5-10 years and have been continuously evolving, following what seems to be a trend of increasing interest of investing in this particular asset class.

CRAs initially define the entity or instrument they intend to rate. They might assign ratings to project finance debt obligations/instruments (i.e. senior secured and subordinated debt), ratings to project finance issuers, or ratings to public-private partnership schemes. CRAs will also deal with various direct or indirect stakeholders who may be involved in a project finance transaction such as, the sponsors, the investors, the lenders, the contractors, the consultants/advisors, the operators, the off-takers or other relevant actors.

As regards the framework that CRAs employ when assessing project finance creditworthiness, this usually pertains to a process which involves different steps. Typically, CRAs check whether a particular issue or issuer to be rated is eligible to be assessed by their project finance methodology (applicability of methodology). Further, CRAs proceed with a step-by step analysis of the different factors that determine creditworthiness (analysis of credit factors)and employ different approaches as well as sequencing when addressing each factor. For example, they might start their assessment from reviewing either the operational or the construction elements of the project, or any other factor they deem appropriate. Typically, during the last steps of this process, CRAs might conduct necessary adjustments (for example, in terms of notching or capping) after evaluating other supplementary elements (consideration of adjustment features).

As a norm, CRAs distinguish between the construction and the operation elements of a project. They may assess construction risks and other features relevant to the construction phase, such as the project/budget timeliness, the complexity of the project, the contractors' previous track records, the technology, the funding provisions and the project flexibility. As regards the operations phase and the operational risk, CRAs would potentially look at performance, financials and relevant counterparties.

Whether in the operation or the construction phase (depending on the methodology), CRAs incorporate in their evaluations elements attributed to pure financial analysis. A non-exhaustive list includes the revenues and cost structure, the capital structure, cash flow analysis, debt metrics (including interest rates and payment maturity), financial flexibility, liquidity and refinancing. With reference to counterparties (contractors, off-takers, guarantors etc.), CRAs assess the relevant framework in different ways, such as by conducting counterparty risk assessments, review of previous track records of counterparties and analysis of contracts (construction, supply, purchase or PPP contracts). CRAs also look at project-specific features such as the project companies, managerial and organizational changes, support from either the sovereign or parent affiliates and guarantee levels. Additionally, an analysis of the external environment is usually factored within the assessment of creditworthiness, through country/sovereign risk evaluations (derived from sovereign ratings), market and competition risk analysis, and risk analysis of external events (concerning regulatory reforms, institutional establishments, tax regimes etc.). Finally, in accordance with their methodology, CRAs could consider the aforementioned factors either as core elements of their credit assessment or as adjustment features.

Table 1. Key steps and rating factors for infrastructure projects by CRAs (Source: Authors)

\begin{tabular}{|c|c|c|c|}
\hline Steps in rating process & \multicolumn{3}{|c|}{$\begin{array}{l}\text { - Definition of entity or instrument } \\
\text { - Applicability of methodology } \\
\text { - Analysis of credit factors } \\
\text { - Consideration of adjustment features }\end{array}$} \\
\hline \multirow{6}{*}{ Rating factors } & Construction phase & $\begin{array}{l}\text { - construction risk } \\
\text { - project / budget timeliness } \\
\text { - complexity of project } \\
\text { - contractors' track records }\end{array}$ & $\begin{array}{l}\text { - technology } \\
\text { - funding provisions } \\
\text { - project flexibility }\end{array}$ \\
\hline & Operation phase & $\begin{array}{l}\text { - operational risk } \\
\text { - performance }\end{array}$ & - financials \\
\hline & Financial analysis & $\begin{array}{l}\text { - revenues / cost structure } \\
\text { - capital structure } \\
\text { - cash flow analysis } \\
\text { - debt metrics }\end{array}$ & $\begin{array}{l}\text { - financial flexibility } \\
\text { - liquidity } \\
\text { - refinancing }\end{array}$ \\
\hline & Counterparties & $\begin{array}{l}\text { - counterparty risk assessments } \\
\text { - track records of counterparties }\end{array}$ & - analysis of contracts \\
\hline & Project-specific features & $\begin{array}{l}\text { - project companies } \\
\text { - managerial / organizational changes }\end{array}$ & $\begin{array}{l}\text { - support from sovereign / parent affiliates } \\
\text { - guarantees }\end{array}$ \\
\hline & External environment & $\begin{array}{l}\text { - country / sovereign risk evaluations } \\
\text { - market / competition risk }\end{array}$ & - risk analysis of external events \\
\hline
\end{tabular}


Table 1 consolidates in a summarized format, the CRAs' methodological framework, and in particular the different steps and the rating factors / drivers, which are used to rate infrastructure projects.

\section{Methodological Considerations}

Considering the factors that are currently used for the credit assessment of transport PPP projects particular emphasis should be placed to their relative importance in the assessment methodology. Depending on the specific risk profile of the project in consideration, there is a danger that certain risks could be overlooked and more emphasis could be placed on "public sector assistance" measures and "credit enhancement", as well as on the corporate profiles of the sponsors. This emphasis would appear to overlook the fact that PPPs are governed by an SPV, which is a special purpose entity representative of the status of the project, i.e. the SPV is as financially healthy as the project it represents.

The above observation highlights a significant conceptual difference that could potentially emerge regarding the different approaches currently used to derive project credit assessments: the key factor and consideration in a PPP setup should be the allocation of risks to the parties most capable of managing them and not only to the parties most capable of bearing the risks in case they materialise.

Additionally, there are specific reasons that could explain an observed bias towards placing a disproportionate emphasis on construction compared to other phases of a project's life-cycle. Clearly, this phase is the most capital-intensive and the repayment of debt that is issued during construction can only start once this phase is over, i.e. the infrastructure needs to be built in order to enter in its operating phase and start generating revenues. The added emphasis on the construction phase may also be related to the fact that project credit ratings were primarily developed for PPP projects that sought financing from the capital markets as opposed to projects that were financed by the banking sector. Although banks have developed extensive expertise in dealing with construction risk, capital market investors usually lack this level of sophistication or expertise and are consequently inherently averse to this risk.

However, the construction phase risk can be considered quite manageable: on the one hand, this is the phase in which the parties involved are more able to manage and bear their corresponding risks (e.g. construction contractors are experts in construction; construction bank loans ${ }^{1}$ are disbursed in tranches after progress has been verified, etc.) and, on the other, it represents just a small part of the entire lifetime of the arrangement. Last but not least, once completed, construction presents limited risk to the remainder of the project's life and performance ${ }^{2}$.

In addition, the emphasis placed on the assessment of construction phase risk versus all other project phases may also be due to the scarcity of data and respective contractual information, which in many cases is

\footnotetext{
${ }^{1}$ In the case of bank financing.

2 Construction defects that may affect future maintenance cash-flows can be covered through contractor warranties and/or third-party insurance.
}

considered confidential and not disclosed even to collaborators. This fact could render the project's credit assessment a cumbersome and deficient undertaking as it is left to rely only on factors that may be observed externally. An example is the importance placed on Legal and Regulatory issues with respect to the concession or PPP agreement. As such, there are very few instances in which default or other negative impacts were observed due to changes in the respective legislation. On the contrary, in many cases where there have been adverse effects, exceptions were regulated. Nevertheless, there have been changes in regulations that have a direct influence on PPPs, such as the Basel II and III committee regulations, through their impact on the banking sector and its lending appetite and capabilities.

Finally, credit assessments could many times employ specialised evaluation criteria depending on the type of infrastructure under consideration. However, a few key elements that are inherently characteristic of the nature of transport assets should not be omitted, such as competition, network effects and demand risk. Emphasis should be shifted to the project per se and not be solely focused on the counterparties of the agreement. Last but certainly not least, credit assessments should consider the effect of managerial flexibility (real options, flexible construction etc.), which would allow for improved risk management efficiency. This is important given that being able to manage risks is equally important and comes a step earlier than the ability to bear the impact of risks that have materialised, and this is an aspect of PPP structuring that is missing from current credit assessments.

\section{Proposed Methodological Framework}

As explained previously, the PPP model of project delivery differs from typical corporate finance transactions with respect to the entities liable for its potential success or failure. The SPV in many cases is totally independent from the project sponsors - the corporate entities awarded the contract. Liabilities are contractually shared based on risk allocation between the SPV and the contracting government authority. As risks vary over time, liabilities may also pass from the SPV to the government authority and vice-versa. Finally, as the Public will always have a vested interest in the project, its viability depends greatly on the ability of the public sector counterparty to honour its commitment to the project.

From this viewpoint it is evident that central in assessing the creditworthiness of a PPP project is the specific contractual agreement describing the allocation of risks; the specificities of the project over time (i.e. project performance); and the characteristics of the public authority and the country the project is implemented in. Notably, in any PPP contractual agreement all risks are not always equitably allocated. For a variety of reasons, in many cases risk is not borne by the party most capable to manage it. This discrepancy increases the cost of the project as it introduces an increased risk premium which is required (or demanded) by the party undertaking an inappropriate risk. It also reduces the creditworthiness of the project, as the respective party may not able to manage the risk. Indeed, project credit assessments should reflect not only the evaluation of the risks involved in the project 
but also of the allocation that took place in each case. The assessment then shifts to the creditworthiness of the parties undertaking the risks and factors that may influence their ability to effectively respond to and cope with the risk eventuating.

As illustrated in Figure 2, the contractual agreement describing risks that have been considered in the transaction, their individual assessment, and their allocation, is at the heart of the proposed conceptual framework. Contractual arrangements through which risks are mitigated, assured, capped or transferred are also important. Equally important are (real) options and other forms of embedded flexibility that may provide the opportunity of managerial adaptation to prevailing conditions [10].

As risks vary over time, the key risks assessed in the evaluation of creditworthiness should also change over time. In turn the credit assessment of a project should also be tied to the specific time it is issued. In this context, risks anticipated in previous project phases should be eliminated from the process or re-assessed as to their impact with respect to the likelihood of future credit default. Risks anticipated in future phases should also be re-evaluated based on credible scenarios updated to reflect current information and knowledge and their impact on future projections regarding project performance.

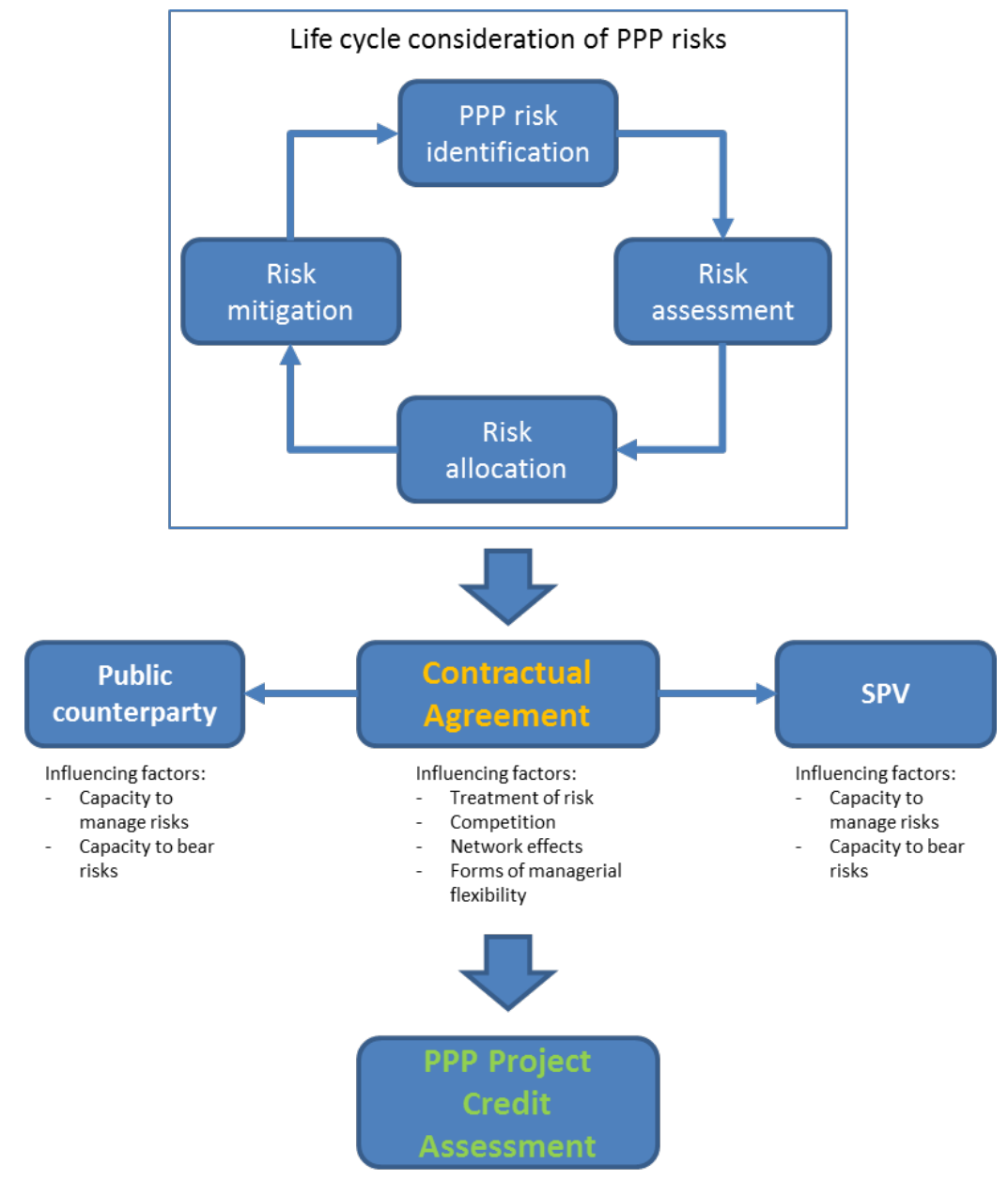

Figure 2. PPP Credit Assessment Conceptual Framework - Key Features (Source: Authors)

Finally, while transport is the most popular sector, at least in Europe, with respect to project development via the PPP route, it is incorrect to assume that all transport infrastructure projects have similar characteristics. Consequently, the construction and operation of the respective facilities do not share the same risk profile. Furthermore, following the above analysis, it is obvious that the proposed assessment of liabilities and how they impact a project's credit assessment is predominately focused on risk allocation as registered in the PPP contractual agreement.

\section{Conclusions and further research}

The anticipated benefits from changing the financial basis of a PPP project over its contractual life cycle highlight the need of introducing project credit assessments. These concern the assessment of the likelihood of default on obligations or delayed payment of debt. In the context of PPPs they are directly connected to project risks and their evolution over the life-cycle of the contractual agreement. Risks and their allocation are at the heart of any PPP agreement. This paper emphasises the difference between managing a risk and being able to cope with a risk eventuating, as it is possible that the respective capability (i.e. management and/or coping), may not be found within the party to which the risk has been allocated. Furthermore, in order to derive project credit assessments, full and in-depth knowledge of how risks are shared is required, along with all potential guarantees that may exist. To this end, the paper offers a conceptual framework for the project credit assessment that aims to complement existing methodologies and practices. 
This framework, which is based on a generic classification of risks encountered in a PPP project's lifecycle, drives us to specific considerations concerning the methodological approach that could be followed in conducting credit analysis of PPP projects. A primary observation is that the emphasis should not shift from the project to the project sponsors or the public sector counterparty as this may not necessarily reflect the risk status of the project itself. Additionally, many assetspecific parameters which are fundamental to the role and operation of transport infrastructure, such as competition, network effects, and demand risk, should be incorporated in the methodological approaches and should be given the appropriate weight where and when they are.

Further research is required with respect to transforming the proposed conceptual framework into an actual project credit assessment methodology and developing a standardised process by which comparable and accurate project credit assessments may be derived, starting with transport infrastructure and potentially extending to other types of economic infrastructure.

\section{References}

[1] Aziz, A.M.A. (2007) Successful delivery of Public-Private Partnerships for infrastructure development, Journal of Construction Engineering and Management, 133(12), 918-931.

[2] European Investment Bank. (2005). Evaluation of PPP Projects Financed by the EIB. EIB Publications.

[3] Engel, E. M. R. A.; Fischer, R. D.; Galetovic, A. (2010) The economics of infrastructure finance: Public-private partnerships versus public provision, EIB Papers, ISSN 0257-7755, Vol. 15, Iss. 1, pp. 40-69.

[4] Yescombe, E. 2007. Public private partnerships: Principles of policy and finance. Amsterdam: Elsevier.

[5] Cantor, R. and Parker, F. (1994) The Credit Rating Industry, FRBNY Quarterly Review, Summer- Fall, pp 1-26.

[6] Gatti, S. (2013). Project Finance in Theory and Practice: designing, structuring, and financing private and public projects, Academic Press.

[7] Grimsey, D. and Lewis, M.K (2002). Evaluating the risks for public private partnerships for infrastructure projects. International Journal of Project management, Vol. 20, pp. 107118.

[8] Checherita, C. and Gifford, J. (2008) Risk Sharing in PublicPrivate Partnerships: General Considerations and an Evaluation of the U.S. Practice in Road Transportation. Transportation Research Board Conference. Available at: http://www.trforum.org.

[9] Kwak, Y.H., Chih, Y. and Ibbs, W. (2009) Towards a Comprehensive Understanding of Public Private Partnerships for Infrastructure Development. California Management Review.
[10] Pellegrino R., Vajdic, N., Carbonara, N. (2013) "Real option theory for risk mitigation in transport PPPs", Built Environment Project and Asset Management, Vol. 3 Iss: 2, pp 199-213.

[11] Roumboutsos A.,Pellegrino, R., Vanelslander, T. and Macario, R. (2012) Risks and Risk Allocation in Transport PPP projects: a literature review InRoumboutsos A. and Carbonara, N. COST Action TU1001, Public Private Partnerships: Trends \& Theory, 2011 Discussion Papers.

[12] Roumboutsos, A., Nikolaidis, N. and Witz, P. (2013) Post Crisis Public Private Partnership Models for Transport Infrastructure, WCTR, Rio de Janeiro July 2013.

[13] Ball, R, Heafey, M. and King, D. (2003) Risk transfer and value for money in PFI projects, Public Management Review. Vol.5, No.2, pp. 279-290.

[14] Anderson, A and LSE Enterprise (2000) Value for Money Drivers in the Private Finance Initiative, report commissioned by the UK Treasury Task Force on Public-Private Partnerships.

[15] Hodge, G.A. (2004) The risky business of public-private partnerships. Australian Journal of Public Administration, Vol.63, No.4, pp. 37-49.

[16] Loosemore M., Raftery J., Reilly C., Higgon D. (2006) Risk management in projects. London: Taylor \& Francis.

[17] Grimsey D. and Lewis M.K. (2004) Public private partnerships. Cheltman, UKA Edward Elgar.

[18] Monteiro, F. (2003), The Concession Process in the Portuguese Port Sector, IST, Technical University of Lisbon, Master in Transports Thesis.

[19] EPEC (2011) State Guarantees in PPPs: A Guide to Better Evaluation, Design, Implementation and Management.

[20] Fitch Ratings (2013), Rating Criteria for Availability-Based Projects, Sector-Specific Criteria, Global Infrastructure and Project Finance, 18 June, 2013, www.fitchratings.com.

[21] Fitch Ratings (2012), Rating Criteria for Infrastructure and Project Finance, Master Criteria, Global Infrastructure and Project Finance, 11 July 2012, www.fitchratings.com.

[22] Moody's Investors Service (2014), Construction Risk in PrivatelyFinanced Public Infrastructure (PFI/PPP/P3) Projects, 10 April 2014, www.moodys.com.

[23] Moody's Investors Service (2010), Generic Project Finance Methodology, 20 December2010, www.moodys.com.

[24] Moody's Investors Service (2007), Operating Risk In PrivatelyFinanced Public Infrastructure (PFI/PPP/P3) Projects, 19 December 2007, www.moodys.com.

[25] Standard and Poor's (2014)(a), Project Finance Framework Methodology, 16 September 2014, www.standardandpoors.com.

[26] Standard and Poor's (2014)(b), Project Finance Transaction StructureMethodology, 16 September 2014, www.standardandpoors.com.

[27] Standard and Poor's (2014)(c), Project Finance Operations Methodology, 16 September 2014, www.standardandpoors.com.

[28] Standard and Poor’s (2014)(d), Project Finance Ratings Criteria Reference Guide, 16 September 2014, www.standardandpoors.com.

[29] Standard and Poor's (2013), Project Finance Construction Methodology, 15 November 2013, www.standardandpoors.com.

[30] Standard and Poor's (2011), Project Finance Construction And Operations Counterparty Methodology, 20 December 2011, www.standardandpoors.com. 